\title{
A TERÜLETI TŐKE SZEREPE A VIDÉKFEJLESZTÉSBEN ${ }^{58}$
}

\begin{abstract}
In the rural development trends related to Hungary, the approach of territorial capital can be an effective tool for creating synergies not only for the development of villages, but also for thinking in the region. The presentation of the international and Hungarian literature related to the theory and practical application of territorial capital contributes to the examination of Hungarian relations. In this study, my aim is to present how the concept of territorial capital can be applied and why it is needed in rural development. As a prelude to this, I will briefly show how the countryside is changing after the change of regime and why its development is important.
\end{abstract}

\section{Bevezetés}

Az elmaradott vidéki térségek felzárkóztatásának, a területi, a társadalmi és gazdasági hátrányok leküzdésének elősegítése a társadalomtudományos kutatás egyik kiemelt feladata. Diplomamunkámban napjaink vidékfejlesztési lehetőségeivel foglalkoztam, melynek során megvizsgáltam egy olyan településfejlesztő szervezetet, amely öt vidéki település összefogásából alakult ki. A munkám folytatásaként a területi tőke koncepciójával kezdtem foglalkozni, mely egy átfogó megközelítés egy adott terület tőketípusainak, azok mennyiségének, minőségének, valamint összetételének felmérésére. Ez egy olyan lehetőség, mely segítségével a hanyatló vidéki települések tőketényezői meghatározhatóvá válnak, hozzájárulva a fejlesztendő területek, és az előrelépést akadályozó tényezők felismeréséhez. A közgazdaságtan, a regionális tudományok és a szociológia is foglalkozik a területi tőke kérdéskörével, melynek különlegességét a különféle erőforrások egy térségen belüli felmérése és felhasználása jelenti.

A Magyarországhoz kapcsolódó vidékfejlesztési trendekben a területi tőke megközelítése nem csak a falvak fejlesztéséhez, de a térségben gondolkodáshoz is hatékony, szinergiákat teremtő eszköz lehet. A magyar viszonyok vizsgálatához hozzájárul a területi tőke elméletével és gyakorlati alkalmazásával kapcsolatos nemzetközi és magyar szakirodalom bemutatása. Ebben a tanulmányban az a célom, hogy prezentáljam, hogyan lehet alkalmazni és miért van szükség a területi tőke koncepciójára a vidékfejlesztésben. Ennek előzményeként röviden bemutatom hogyan alakul át a vidék a rendszerváltás után és miért fontos a fejlesztése.

\section{A vidék átalakulása és új kihívások a vidékfejlesztés előtt}

\footnotetext{
${ }^{58}$ EFOP-3.6.3-VEKOP-16-2017-00007 azonosítószámú, "Tehetségből fiatal kutató. A kutatói életpályát támogató tevékenységek a felsőoktatásban" megnevezésű projekt a Széchenyi 2020 program keretében, európai uniós (Európai Szociális Alap) társfinanszírozással valósul meg.
} 
A rendszerváltás hatása negatívan érintette a falvakat, hiszen csökkent a munkalehetőség, a városi ingázók visszaszorultak a falvakba, folytatódott a falvak elöregedése, valamint romlott a falusi lakosság egészségi állapota. Mindez összefügg a szociális ellátást igénylők számának emelkedésével, illetve összességében a gazdasági és a társadalmi differenciálódás növekedésével. A rendszerváltás vesztesei igen nagy részben a falusi lakosságból kerültek ki, kiemelten a városoktól távol eső, kis lélekszámú településekről (Bőhm 2005: 82; Juhász 2005: 47, Varga 2005: 59).

A rendszerváltás után mind gazdasági, mind társadalmi, mind fejlesztéspolitikai szempontból rengeteg problémával kell szembesülnünk a falvak esetén. Gazdasági szempontból ilyen nehézség a gazdasági aktivitás elégtelensége, a gyenge helyi tőkefelhalmozási folyamat, az önerőből nem megoldható problémák, a gyenge tőkevonzó képesség, a munkanélküliség, és hogy sok faluban az önkormányzat a legnagyobb munkáltató.

Társadalmi szempontból sokkal rétegzettebb kihívásokról beszélhetünk. Egyrészt a sok mindent meghatározó demográfiai folyamatokról, mint az elöregedő lakosság, a romló egészségügyi állapotuk, az elnéptelenedő falvak, a gyorsuló ütemü leszakadás a városi lakosságtól, a falusi értelmiség elvándorlása, a szakképzetlen munkaerő nagy létszáma és reménytelen helyzete, a helyi hatalomra nagy befolyást gyakorló új vállalkozói réteg, a bérmunkás mentalitás terjedése és a második generációs munkanélküliek megjelenése. Másrészt a falusi életmódot jellemző értékek eltünése, a közösséghez tartozás csökkenő vonzeröje, a hagyományos közösség felbomlása, az individualizációs folyamatok, és a szolidaritási hálók megszakadása. Harmadrészt fontos megemlíteni általánosságban a falvak helyzetét, miszerint a falvak differenciálódnak (szegény és gazdag falvak kialakulása), hiányzik a megújításra képes értelmiség, a falvak sok esetben nem rendelkeznek érdekképviselettel, érdemi területfejlesztési politikával és nincsenek értelmiségi munkahelyek. A fejlesztéspolitika szempontjából fontos megemlíteni, hogy a falvaknak sok esetben nincs sikeres jövőképük, a pályázati lehetőségek kihasználásában az önerő nem tünik elegendőnek, a tőketulajdonosok elköltöznek és a falu változása csak erős külső nyomás hatására megy végbe (Bognár et al. 2005: 32-34).

A 21. századi modernizációs tendenciák mindezek mellett új kihívások elé is állították a falvak lakosságát és a gazdálkodásban résztvevőket., melyeket akár pozitív hatásokként is értelmezhetünk. Olyan új igények jelentek meg, mint a biogazdálkodás, a tájgazdálkodás, helyi termékek közvetlen értékesítése, valamint a felhasználói szükségletek szerinti termelés, melyre a fejlődés érdekében reagálni kellett. Így szükségessé vált a folyamatos tanulás, a kapcsolatrendszerekben való kiigazodás és a jó szervezési készség (Juhász 2005: 50). Ez a fejlődésre lehetőséget adó hatás új, szolgáltatási funkciókkal látta el a falvakat, melyeknek nem minden település tudott eleget tenni. Varga Gyula úgy vélte, hogy a kedvezőtlen helyzetből való kilábalás és a modernizációs igényeknek való megfelelés önerőből nem lehetséges. Új politikára van szükség a vidék felzárkóztatásához, a vidék gazdaságának erősítésére, a vállalkozók letelepedésének támogatására, a vidék tőkevonzó képességének növelésére és a munkaerő szakképzettségi szintjének javítására, hogy a vidéki életszínvonal emelkedhessen. Ennek olyan infrastrukturális feltételei vannak, mint a falvak bekapcsolása az országos 
közlekedési rendszerbe, az ivóvíz és csatornahálózat kialakítása, illetve a hulladékgyüjtés és kezelés rendszerének kiépítése (Varga 2005: 71).

A vidékfejlesztés a rurális térségek fejlesztésével foglalkozik gazdasági, infrastrukturális, társadalmi és turisztikai beruházásokkal, melyek a helyi lakosság életkörülményeinek javítását szolgálják. Így a konkrét vidékfejlesztési programok alkalmazhatók vállalkozások, települési infrastruktúrák és humánerőforrás fejlesztésére, a kulturális örökség, a táj, a környezet védelmére, valamint szociális, turisztikai és közösségfejlesztési programok szervezésére is (Kulcsár 2017: 105).

A vidékfejlesztés nagy figyelmet fordít az agráripar, tehát a mezőgazdasági termelés helyzetének javítására is, ugyanakkor a kétezres évek elején egyre fontosabb elemként jelent meg a vidék, mint a helyi társadalom életterének rehabilitációja. Ez alapján a gazdasági és társadalmi, valamint kulturális elemek, természeti erőforrások együttes fejlesztése révén érhető el a helyi társadalmak életszínvonalának emelése (Pásztohy 2007: 17, Jenkins 2000, Buday Sántha 2001, Szakál 1999, idézi Ludescher 2007: 430).

A vidékfejlesztés középpontjában helyi vonatkozásban, sok esetben a helyi közösségek, aktív szereplők és az ő tevékenységük, cselekvéseik állnak, melyek irányulhatnak a fizikai környezet, mint infrastruktúra fejlesztésére, valamint olyan folyamatokra, mely az embert és az emberi kapcsolódásokat helyezi az előtérbe (Reisinger 2010: 155). Így a helyi fejlesztések szempontjából kiemelt fontossággal bír a helyi társadalmak összefogása, együttmüködése, hogy a társadalmi kohézió erejével hatékonyabb és hosszútávon is fenntartható fejlődést érhessenek el (Ludescher 2010: 33-35).

Összegzésként tehát, a vidékfejlesztés kulcsa a helyi kulturális sokszínűség fenntartása mellett a vidéki problémákra történő reakció, az integrált megközelítés, a szubszidiaritás és a vidéki emberek közösségi aktivitása. Ezeknek a folyamatoknak a hátterében növekvő szerepe van a bürokráciának, a szellemi erőforrásoknak, a vidéki értelmiségnek, valamint a helyi középosztálynak (Font 1999: 9-17, Kovács 1999: 175-177, Kulcsár 1999: 179-187, Rechnitzer 2010: 10-11).

\section{A területi tőke bemutatása}

Az Európai Unió kohéziós és vidékfejlesztési politikája a területiség és az endogenitás elvének bevonásával a helyi igényekhez igazodó, helyben elérhető erőforrások használatára biztatja a közösségeket. A területi sokféleség, a versenyképesség, és a területalapú megközelítés, így fontos hívószavak lettek, melyre a területi tőke koncepciója igazodni látszik. Képes alkalmazkodni a helyi igények felméréséhez, a helyi erőforrások megfelelő és hatékony felhasználásához. (Amodio et al. 2019: 75-89).

A területi tőke fogalmát az OECD 2001-es dokumentuma (Territorial Outlook) említi először, mely a területi és gazdasági különbségeket is kiemeli a fejlesztéspolitika szemszögéből (Dombi et al. 2017: 27). Az interdiszciplináris szemléletmód lehetővé tette, hogy a materiális tőkeelemeken túl az immateriális tőkék hatását is figyelembe vegyék a gazdasági fejlődés vizsgálatakor. A területi tőke megközelítése tehát egy adott térségben (régióban, megyében, 
településen) megtalálható tőketípusok összetételét és mennyiségét méri fel, így rámutatva a fejlesztési lehetőségekre, illetve hiányosságokra (Jóna 2013: 33).

Az OECD 2001-es dokumentuma szerint a területi tőke a következő tényezőkből áll össze:

1. földrajzi fekvés és méret;

2. éghajlati és természeti viszonyok;

3. termelési tényezőkkel való ellátottság;

4. agglomerációs gazdaság, ipari parkok, vállalkozói hálózatok;

5. hagyományok, felfogások, szokások, szolidaritás, kölcsönös segítségnyújtás, ötletek egyeztetése (társadalmi tőke);

6. intézményi szabályok, gyakorlatok, vállalkozók, kutatók és szakpolitikusok (Dombi et al. 2017: 27).

Fontos megemlíteni a különböző tudományágak azon nézeteit, melyek a „tőke” valamilyen típusával foglalkoznak, így nem csak a gazdasági tőkét kell szem előtt tartani. Épp úgy tőkeként lehet tekinteni a társadalmi és kulturális tőkére (Bourdieu, 1998), mint a strukturális és intézményi tőkére, vagy éppen mindezek együttmüködési készségére. A fenntartható fejlődés trendjének egyre szélesebb körü elterjedésével a természeti tőke, a kreativitás tőke és a kapcsolati tőke kooperációja is tőkének minősül (Dombi et al. 2017: 2426).

\section{1. táblázat: A területi tőke csoportosítása}

\begin{tabular}{|c|c|c|c|}
\hline \multirow{2}{*}{ Versengés szintje } & \multicolumn{3}{|c|}{ Anyagi megjelenés } \\
\hline & Materiális tőke & Vegyes tőke & Immateriális tőke \\
\hline Magánjavak & Magán állótőke & $\begin{array}{c}\text { Kapcsolati } \\
\text { magánszolgáltatások }\end{array}$ & Humán tőke \\
\hline $\begin{array}{c}\text { Klubjavak-kevert } \\
\text { javak }\end{array}$ & Köztes-kollektív javak & Kooperációs hálózatok & Kapcsolati töke \\
\hline Közjavak & Közjavak és források & $\begin{array}{c}\text { A fejlesztéshez } \\
\text { kapcsolódó } \\
\text { alkalmazkodóképesség, } \\
\text { nyitottság }\end{array}$ & Társadalmi tőke \\
\hline
\end{tabular}

Forrás: Saját szerkesztés Camagni (2008) alapján.

A területi tőke tárgyalásának szempontjából kiemelendő Roberto Camagni (2008) 3x3as mátrixban meghatározott csoportosítása, melynek fó szempontja az anyagi megjelenés, valamint a versengés szintje. Az anyagi megjelenés alatt a materiális, illetve az immateriális tőke típusokat kell érteni, a versengés szintje pedig azt jelenti, hogy magán vagy közjavakról beszélünk.

Az anyagi megjelenést alapul véve az alábbi tőketípusok lehetségesek: materiális tőke közé a magán állótőke, a köztes - kollektív javak, valamint a közjavak és források tartoznak. A vegyes tőkéhez sorolja a kapcsolati magánszolgáltatásokat, a kooperációs hálózatokat, valamint a fejlesztéshez kapcsolódó alkalmazkodóképességet és az előnyök kihasználására való 
képességet. Az immateriális (nem tárgyi) töke pedig a humán tőkét, a kapcsolati tőkét és a társadalmi tőkét jelentik (Camagni 2008: 37-38).

Az 1. táblázatban szemléltetett mátrix kevésbé egyértelmü fogalmainak értelmezéséhez Jóna György (2013) tanulmányát veszem alapul, amely a területi tőke fogalmi modelljét elemzi Camagni (2008) alapján. A köztes-kollektív javak kategóriájába a kulturális örökség, a kommunikációs hálózat, a müszaki berendezések és az úthálózat tartozik, míg a közjavak és forrásokhoz az adott térségben található anyagi tőkék (például termőföld) és infrastruktúra (például szennyvízhálózat) kapcsolódik. A középső oszlop értelmezésénél a kapcsolati magánszolgáltatások körébe a vállalatok és a $\mathrm{K}+\mathrm{F}$ szektorhoz tartozó profitot realizáló együttműködések tartoznak (vállalkozások és egyetemek gazdasági fejlődést eredményező összefogása), a kooperációs hálózatok a magán- és köztulajdonban lévő tudásintenzív gazdasági egységek és a térség kulturális intézményrendszere között teremtenek kapcsolatot. Az immateriális javak közül a humán tőke jelen esetben a vállalkozói készséget, a kreativitást és a magán know-howt jelenti, a kapcsolati tőke az együttmüködési képességet, a kollektív kompetenciákat, a társadalmi tőke pedig az intézményeket, magatartásmintákat, értékeket és a bizalmat foglalja magába (Jóna 2013: 40-45).

A területi tőke definiálására több kísérlet is született, melyekből a következő sok szempontot foglal magában: „A területi tőke egy földrajzi térség esetében a gazdasági értéktermeléshez kapcsolódó (a gazdasági értéktermelésben résztvevő, avagy arra ható), anyagi (materiális) és nem anyagi (immateriális), köz-, vegyes vagy magántulajdoni formában lévő, a térbeli együttességből eredően egymással különböző kombinációkat, s így egyedi struktúrákat alkotni képes endogén jellegü tényezők összessége" (Dombi et al. 2017: 36).

Szem előtt tartva, hogy a területi tőke koncepcionális keretét a fejlesztések eszközeként, esetleg a fejlődés irányainak meghatározásához szeretnénk felhasználni, meg kell vizsgálni a mérhetőségét is. A dolgozatba bevont kutatások tekintetében kijelenthető, hogy ahány vizsgálat, nagyjából annyiféleképpen közelítették meg a területi tőke mérését. Elsőként azt kell megállapítani, hogy mire vonatkozik a mérés, milyen indikátorok, egyáltalán mely tőkék kerüljenek bevonásra, hiszen sok esetben, csak bizonyos tőketípusok vizsgálata válik szükségessé. A megfelelő indikátorok száma és csoportosítása sincs kőbe vésve. A kutatók sok esetben úgy igyekeztek meghatározni az alkalmas mutatókat, hogy azok igazodjanak a területiség elvét előtérbe helyező Territorial Agenda 2020 dokumentumához és az EU 2020 stratégiai prioritásaihoz is (Dodescu et al. 2018: 97). Kvantitatív és kvalitatív módszerekkel egyaránt dolgoztak a tanulmányok. A kvantitatív mérések esetén a leggyakoribb, hogy a területi tőke mennyiségi meghatározására és nagyobb térség lefedésére törekszenek. A kvalitatív módszerek a területi tőke összetételére és kisebb területi egységre alkalmazhatók nagyobb eredményességgel. A legteljesebb képet a két mérési típus kombinációjával kaphatjuk, hiszen kiegészíthetik egymás sötét foltjait, így segítve a fejlesztési koncepció kidolgozását (Dombi et al. 2017: 55-58).

\section{A területi tőke a kutatások szemszögéből}

A területi tőkével kapcsolatos kutatások alapvető közös vonása, hogy a területiség elvét helyezik a vizsgálatuk középpontjába. Akár külföldi, akár hazai elemzésekről van szó, mind 
különböző módszerekkel igyekszik felmérni egy-egy területi egység tőkeállományát. Az alábbiakban néhány kutatást mutatok be, melynek segítségével betekintést nyerhetünk a területi tőke koncepciójának sokszínű alkalmazásába. A bemutatás során a kutatási területekre, a területi tőke vizsgált elemeire, a felhasznált módszerekre, az eredményekre, és a korábbi vizsgálatokhoz viszonyított újdonságokra koncentrálok.

\section{Nemzetközi kutatások}

A feldolgozott területi tőke kutatásokat Európán belül maradva mutatom be, amelyeket csoportosítani lehet Dél-Nyugat- és Közép-Kelet-Európában elvégzett vizsgálatok szerint.

Elsőként Affuso és Camagni (2010) közös munkáját ismertetem, melyben Franciaország, Olaszország és Spanyolország régióit hasonlítják össze a területi tőke tekintetében. Céljuk egy új ökonometriai modell kidolgozása tartományi szinten, mely magyarázza a NUTS3-on belüli GDP növekedés különbségét a NUTS2 GDP növekedési rátájához viszonyítva, tehát a modell célja a különböző növekedés okainak azonosítása. A magyarázó változók négy csoportját az infrastrukturális tőke és települési struktúra, az ágazati és természeti sajátosságok, a kognitív tőke és a társadalmi tőke alkotják kutatásuk esetén.

A területi tőkét úgy definiálják, mint helyi eszközök, amelyek az adott terület versenyképességi potenciálját határozzák meg. Olyan tényezőket is a területi tőke részének tekintenek, mint konszenzusok, szokások, informális szabályok, kölcsönös szolidaritás (társadalmi tőke), valamint intézményi szabályok, gyakorlatok, termelők, kutatók és politikai döntéshozók kombinációja.

A kutatás eredményeit összegezve azt lehet mondani, hogy a latin térség nem homogén tér, és hogy a területi tőke elemei magyarázzák a differenciált növekedési arányokat a három különböző ország esetén. A francia tartományokban az ágazati sajátosságok játszák a fó szerepet, valamint a migráció és a humán erőforrás kapcsolatát vizsgálva megállapították, hogy a bevándorló munkaerő pozitív hatással van a befogadó térség gazdasági fejlődésére. Olaszországban a területi struktúra alapvető fontosságú a növekedés különbségeinek magyarázata szempontjából, így például az ipari foglalkoztatás arányának pozitív és jelentős hatása van az agglomerált tartományokban, de összességében negatív hatást gyakorol. Spanyolországban pedig a növekedés különbsége mind a négy fent említett tényezőcsoporthoz tartozó elemekből fakad, melyekből néhánynak a másik két vizsgált országhoz képest pozitív és szignifikáns hatása van (például a választásokon való részvétel vagy az úthálózat szerepe a gazdasági növekedésben) (Affuso - Camagni 2010: 1-15).

Martinoia és Pompili (2015) célja az volt, hogy elemezze a területi tőke immateriális összetevőinek szerepét a már megvalósult rövid és hosszútávú regionális fejlesztésekben kiemelve a természeti, a kulturális és a humán tőkét. A 103 olasz tartomány vizsgálata során olyan mutatókkal dolgoztak, melyeket a természeti örökség, a történelmi, művészeti és kulturális örökség, idegenforgalmi ágazat, iskolázottság, szakmai készségek és a munkaerőpiaci helyzet foglal magába.

A területi tőkét összességében úgy állapítják meg, mint ami különféle eszközöket tartalmaz, melyek felhalmozódtak egy területen, és a megfelelö kiaknázásukkal biztosítható a 
versenyképesség, növelhető a vonzerő és fejleszthető a gazdaság. Részletesen a természetikulturális tőkét, valamint a humán tőkét elemzik empirikusan, hogy elkészítsék az olasz tartományok tipológiáját klaszterelemzés és faktoranalízis segítségével. Eredményeik közé tartozik, hogy a humán tőke Olaszországban megerősítette a jól ismert észak-déli kettősséget, ráadásul a déli térségek és a szigetek belsőleg sokkal homogénebbnek bizonyultak, mint az északi és a középső területek (Martinoia - Pompili 2015: 1-35).

Nem csak statisztikai módszerekkel vizsgálták a területi tőkét, hanem fókuszcsoportos interjút is alkalmaztak, például Tortora et al. (2014) kutatásában. Ez egy feltáró tanulmány az állami szereplők jövőképének bemutatására és a fejlesztés mozgatórugóinak tárgyalására a turisztika szempontjából a történelmi múlt és tőkék, valamint versenyképesség alapján. Vinci, egy agráripari település a kutatás helyszíne, mely fontos természeti tőkével és kulturális örökséggel rendelkezik, ami a turizmus fejlesztése szempontjából fontos lehet.

A közösségalapú és fenntartható tervezési megközelítésnek három fontos elemét nevezték meg, melyek a következők: a közösség és a turizmus résztvevői által kialakított nézőpontok; konszenzus és beleegyezés elérése a jövőre nézve; egy hosszútávú fejlődési cél megfogalmazása. Fókuszcsoportos interjútechnikát alkalmaztak, mivel az információk mélysége és minősége fontos szempont volt. Ennek során feltárták és megvitatták Vinci fejlődésének lehetséges jövőképét az erősségekre és gyengeségekre fókuszálva, valamint szó esett a tapasztalatokról és véleményekről az idegenforgalmi folyamatok ösztönzése kapcsán. A kutatás eredményeként megállapították, hogy Vinci összetett turisztikai jellemzőkkel rendelkezik, azonban nem született kompromisszum a fejlesztés irányát tekintve (Tortora Randelli - Romei 2014: 1-11).

Chaterine Dezio (2020) cikke Olaszország belső vidéki területeit vizsgálja, illetve azok regenerációs potenciálját a mezőgazdaság és a hozzá kapcsolódó agrártevékenységek fejlesztése által. A vidéki örökséget a különféle erőforrások tárházaként értelmezi.

A vizsgálat tárgyát, a belső területeket úgy határozta meg, mint a központok kínálatától jelentősen távol eső területeket, ahol jelen vannak az alapvető szolgáltatások, környezeti szempontból és kulturális erőforrásokban gazdagok, valamint természetüknél fogva sokszínűek. A fejlesztés első lépcsőfokának az alapvető szolgáltatások kínálatának kiigazítását javasolja, mint a területfejlesztés előzetes feltétele. A második lépcsőfokot a munkahelyteremtésre irányuló beavatkozásokként határozta meg. A beavatkozást nem a hagyományos fentről lefele irányuló segítségnyújtással képzeli el, hanem endogén fejlesztési tendenciákkal, mely megfelel az Európai Unió irányelveinek. Hiányosságnak tartja a szerző, hogy bár az elvek szinkronban vannak, nem foglalkoznak a megfelelő mutatók kidolgozásával, amelyek meghatároznák a vizsgált területek állapotát.

Mindezt tehát a mezőgazdasági fejlesztések szempontjából közelíti meg, melynek kapcsán a területi tőke négy dimenzióját vizsgálja meg: kulturális tőke, természeti tőke, humán tőke és gazdasági tőke. Kiemeli, hogy a mezőgazdaság egy nagyon összetett szektor, mely az élelmiszertermelésen túl a hulladékgazdálkodást, a takarmány- és vegyipart, a textilipart, az energiaipart és az ökoszisztémával kapcsolatos védelmi tevékenységeket is magába foglalja, valamint sok társadalmi szereplőt is tömörít (Dezio 2020: 209-215). 
Bogdanov és Jankovic (2013) munkáját azért tartom fontosnak megemlíteni, mivel a vidéki területek fejlesztési lehetőségeit vizsgálták a turizmussal összefüggésben, Szerbia régióiban. A tanulmány célja annak meghatározása volt, hogy a kiválasztott területeken a területi tőke jelenlegi dimenzióinak alakulása összhangban van-e a vidéki turizmus fejlesztésének tervezett irányaival. Kvantitatív kutatásukat interjútechnikával ötvözték, hogy mélységében felmérjék a fejlesztés lehetséges irányait.

A kutatás eredményeként Szerbia négy nagyobb területi egységére is megállapításokat tettek. A kelet-szerbiai régió gazdag kulturális, természeti, valamint emberi és társadalmi tőkével rendelkezik, a humán és társadalmi tőke becsült minőségének magas értékei e régióban elsősorban a turizmus fejlesztését célzó számos projektnek tulajdoníthatók, amelyeket az utóbbi években hajtottak végre. A dél-bánáti területeken magasnak számít a humán tőke, a természeti tőke pedig a jó földek mezőgazdasági kiaknázására fókuszál, így a turisztika fejlesztési potenciál kevésbé jelentős. Az Alsó-Duna területeken a természeti és gazdasági tőke vehető figyelembe, de a többi térséghez képest ez is alacsony. Közép-Szerbia térségére a magas gazdasági tőke jellemző, amely a szálláshely kapacitásokból eredeztethető, gyengébb a kulturális vonatkozás, ugyanis a turizmus a hagyományos, természeti szépségekre fókuszál, nincs hálózatépítés és innováció. Tehát a területi tőke elemeinek vizsgálata fontos egy adott vidéki térség turizmusának fejlesztése szempontjából (Bogdanov - Jankovic 2013: 201-230).

Fratesi és Perucca (2014) elvégzett egy olyan vizsgálatot, mely kifejezetten a középkelet-európai régiót értékelte. A cikk célja, hogy elemezzék ezen régiók strukturális jellemzőit, a NUTS3-as térségek gazdasági növekedése és az Európai Unió pénzügyi támogatásai között fennálló kapcsolatot.

A közép-kelet-európai régiókra való összpontosítást azzal indokolták, hogy a 2004-es csatlakozáskor 10 ország egyidejűleg lett jogosult uniós finanszírozásra, ezért aszimmetria nélkül, együttesen tudják vizsgálni a támogatások hatásait. Kiemelik, hogy a kohéziós politika esetén nagyon széles az uniós támogatások skálája, hiszen különböző szakpolitikákra és beavatkozásokra lehet szétbontani. Ez azért fontos, mert a különböző beavatkozások hatása időben eltérhet, így szétbonthatóak rövid és hosszú távú hatásokra. Általában a gazdasági és infrastrukturális beavatkozások rövidtávon várnak eredményeket, míg a társadalmi és fenntarthatósági programok hatásai inkább hosszú távon lesznek megfigyelhetők. Ezek alapján a kohéziós politika eredményeinek területi tőkéje is különbözik a beruházások két tipológiája szerint. Rövid távon valószínűsíthető, hogy a területi tőke megléte, illetve azok magas szintü kihasználása növeli a kohéziós alapok hatását. Hosszabb távon azonban a gazdasági növekedés az előfeltétele annak, hogy a kohéziós alapok nyújtotta előnyöket és a térség területi tőkéjét megfelelően fel tudják használni.

A kutatást empirikusan regresszió-elemzéssel vizsgálták, ahol az egy főre eső regionális GDP alakulását vették alapul. Az elemzés eredményeként megállapították, hogy a regionális politika önmagában nem annyira hatékony, mivel függ a régióban fellelhető területi tőke összegétől. Más szavakkal ez azt jelenti, hogy amely régió jobban fel tudja használni a területi tőke különböző összetevőit, ott a kohéziós alapok hatása is erőteljesebb. A Strukturális Alapok tehát jól müködnek, mint a gazdasági növekedés elősegítői, amikor azok kiegészülnek adott régió területi tőkéjével és annak jó felhasználó képességével. A vidéki területek viszont sokszor 
nem használják ki a nagyobb beruházásokat, ami megkérdőjelezi a strukturális alapok teljes szerepét, mivel ezek a régiók általában a legszegényebbek és kevésbé fejlettek, tehát itt lenne leginkább szükség a beruházásokra (Fratesi - Perucca 2014: 165-191).

Fratesi és Perucca 2020-as tanulmányában megvizsgálta az EU regionális politikájának és a területi tőkének az összefüggéseit, melynek célja a fejlesztéspolitikai folyamatok megértése és javítása volt. Emellett azért is fontos e kettő együttes vizsgálata, mert a régiók nemcsak területi jellemzőik tekintetében különbözhetnek, hanem a politikai döntések végrehajtásának sokszínüségében is.

Az elemzést a 2000-2006 közötti programozási időszakra vonatkoztatva készítették el, melynek célja az EU régióinak osztályozása volt a területi tőkéjük szempontjából, valamint a források elosztásának és a kiadásoknak az összevetése. Megközelítésükben a kohéziós politika hatékonyságát a GDP növekedése határozta meg, vagyis minél magasabb a gazdasági növekedésre vonatkozó statisztikai hatás a politikák végrehajtását követő években, annál nagyobb a kohéziós politika hatása. Ez az elemzés lehetővé tette annak ellenőrzését, hogy a kohéziós politika beruházásai hatással voltak-e a regionális gazdasági növekedésre, és hogy ez a hatás differenciált volt-e különböző területi tőkével rendelkező régiók számára. Tekintettel az EU keleti és nyugati országai közötti strukturális különbségekre, az elemzést ilyen bontásban végezték el.

Összefoglalva elmondható, hogy a kohéziós politika a területi tőke szempontjából hatékonyabb és jobban megtérül a fejlettebb régiókban, mint a gyengébbekben. Ez alapján olyan javaslatokat fogalmaztak meg, miszerint a regionális politika helyi döntéshozóinak meg kell állapítaniuk, hogy adott helyzetben milyen beavatkozásra van szükség. Ez elörevetít egy olyan kutatási irányt, mely a regionális politika hatékonyságát kistérségi szinten mikrogazdasági tényezőket bevonva vizsgálná (Fratesi - Perucca 2020: 29-36).

A gazdasági növekedés és a területi tőke feltáró elemzése: bizonyíték Romániából címmel (Dodescu et al. 2018) megvizsgálták Románia NUTS3-as régióiban (megyékben), hogy a területi tőke különböző dimenziói hogyan hatottak a gazdasági növekedésre, illetve mely tényezőknek volt szignifikáns és pozitív hatása a gazdasági fejlődésre. A területi tőkekomponensek és a gazdasági növekedés kapcsolatát a strukturális egyenletmodellezés módszertanának (SEM) segítségével vizsgálták, amellyel a nem megfigyelt (látens) változók indikátorváltozókkal történő mérése modellezhetővé válik. A statisztikák által elérhető adatok a területi tőke öt összetevőjének azonosítását tették lehetővé: gazdasági, infrastrukturális, intézményi, emberi és társadalmi tőkét.

Kutatásukban két hipotézist vizsgáltak meg, melyek az alábbiak:

1. hipotézis: Minden tőketípus (gazdasági, infrastrukturális, intézményi, emberi és társadalmi tőke) pozitívan, statisztikailag és szignifikánsan korrelál a területi tőkével.

2. hipotézis: Pozitív és statisztikailag szignifikáns kapcsolat van a területi tőke és a gazdasági növekedés között.

A kutatás alapján az egyes hipotézist elvetették, mivel a társadalmi tőke negatívan korrelált a területi tőkével. A második hipotézist a területi tőke két komponensére fogadták csak 
el, a gazdasági és az infrastrukturális tőkére. Az eredmények a következőképp foglalhatók össze:

1. a gazdasági és az infrastrukturális töke pozitív hatása a gazdasági növekedésre;

2. a társadalmi tőke negatív hatása a gazdasági növekedésre;

3. az emberi tőke és az intézményi tőke jelentéktelen hatása a gazdasági növekedésre.

Ezek az eredmények fontosnak tekinthetők a fejlesztéspolitika és a munkaerő-piaci intézkedések, valamint a helyi társadalmak értékteremtése és gazdasági versenyelőnyének kialakítása szempontjából (Dodescu et al. 2018: 95-112).

\section{Magyarországi kutatások}

Tóth Balázs István (2011) több kutatásában is vizsgálja a területi tőke koncepciójának segítségével Magyarország különböző térségeit. Jelen tanulmányában a városi szint, azon belül is a középvárosok kerültek középpontba. Faktorelemzés segítségével vizsgálja a magyar középvárosok területi tőkéjét, materiális és immateriális tényezőket egyaránt, mely segít egy rangsor felállításában, majd klaszteranalízis módszerével csoportosítást végez. A TeIR interaktív elemző adatbázis 2009-es adatait használta kutatásához.

Immateriális erőforrások tekintetében agglomerációs és volt szocialista iparvárosok vannak a legkedvezőtlenebb helyzetben, viszont az infrastruktúra kiépítettsége relatíve kedvező. Azokban a középvárosokban, ahol a települési alapszolgáltatások szintje megfelelö, ott a közművelődés is kedvezően alakul, és ugyanez mondható el a települési környezet és a társadalom állapota vonatkozásában is. A materiális és immateriális erőforrások bizonyos fokig együtt mozognak a hazai középvárosok esetében.

Összességében kutatásából megállapítható, hogy a nyugat-kelet differencia és a fővárosvidék szembenállás napjainkban is jelen van Magyarországon. Azzal a problémával szembesült, hogy sok esetben kevés információ található, vagyis hiányos az adatbázis, különösen humán tényezők tekintetében. Ennek ellenére a tanulmány eredményei elősegítik a települések megfelelőbb pozícionálását a magyar településhálózatban, továbbá azonosíthatóvá vált a települések materiális és immateriális erőforrásainak állapota, így kitűzhetők a jövőbeli fejlesztési irányok (Tóth 2011: 530-543).

Bodnár Gábor (2016) kutatásában a vidék jellemző folyamatait tekinti át többváltozós elemzés segítségével, melyben az egyes tőketényezők megjelenésének és azok térszerkezetének összehasonlítását és a területi egységek tőkeellátottságát vizsgálta. Az európai rurális terek egyre differenciáltabbak és a globalizációval szembeni magatartásukban, identitásukban és erőforrásaikban is különböznek. Magyarországon polarizálódott a vidék egésze, túlsúlyba kerültek a gazdasági és szociális vonatkozású negatív folyamatok, mivel a gazdasági bázist és a nagyüzemekben koncentrálódó helyi értelmiséget a vidék elvesztette.

A megoldási lehetőségként előtérbe kerülő endogén fejlődés elmélete a vidék vonatkozásában is teret nyert. Kutatásába olyan tőketényezőket vont be, melyek szerepet játszhatnak az endogén fejlődésben. Ilyen tőketípus a magán állótőke, humán erőforrás, társadalmi tőke, infrastrukturális tőke, kulturális tőke és a vállalkozási környezet. Statisztikai 
módszerként a faktoranalízist választotta, mely segítségével a fö tényezőkhöz indikátorokat csatolt.

Eredményként megállapította, hogy a magán állótőke az észak-dunántúli területen kiemelkedik a magyar vidékies kistérségek közül. A legmagasabb kategóriába 22 kistérség, a két legalacsonyabba 66 kistérség tartozik, ahol a leggyengébb értékek az alföldi és az északmagyarországi kistérségekben találhatók (Bodnár 2016: 162-184).

Kovács és Bodnár (2016) tanulmányukban szintén vidékies kistérségeket vizsgáltak, melyben a területi tökével és endogén fejlödéssel kapcsolatos tőketényezőket vontak be. Arra voltak kíváncsiak, hogy a kulturális tőke, humán erőforrás, infrastrukturális tőke, társadalmi tőke és a vállalkozási környezet hogyan befolyásolja a magán állótőkét. Modelljük eredményeként megállapították, hogy a társadalmi tőke befolyásolja legnagyobb mértékben a magán állótőke értékét (Kovács - Bodnár 2016: 144-161).

Tóth Balázs István (2014) egy másik kutatásában azt vizsgálta, hogy a helyi tényezők, erőforrások és funkciók megléte, színvonala szoros összefüggésben áll a térségek megítélésével, vonzerőjével. Azt állítja, hogy a helyi sajátosságok nagy mértékben kapcsolatban állnak a területi tőke koncepciójával.

A tanulmány célja, hogy a nemzetközi szakirodalom alapján feltárja és ütköztesse a területi tőkével kapcsolatos empirikus vizsgálatok módszertani megközelítéseit, valamint bemutassa a területi tőke és a helyi vonzerők együttes kutatásának lehetőségeit. Azt is vizsgálja, hogy a területi tőke dimenziói miként függnek össze a belföldi állandó vándorlások számával.

Fő kérdése, hogy statisztikailag igazolható-e, hogy míg a magasabb területi tőkével rendelkező térségekbe a lakosság odatelepül, a szerényebb területi tőkével rendelkezők esetén az elvándorlás figyelhető meg. Mely dimenziók befolyásolják leginkább a tartós belföldi migrációt és van-e számottevő hatása az endogén kapacitásoknak.

Diszkriminanciaelemzés segítségével vizsgálta a kistérségeket 2006 és 2011 között. Megállapította, hogy jelentős mértékủ állandó elvándorlással jellemezhető kistérségek alacsony területi tőkeértékkel rendelkeznek, de humán erőforrás tekintetében kedvezőbb helyzetet mutatnak. Az eredmények alátámasztották, hogy a kistérségek esetében megfigyelhető belföldi migráció függ a kistérségek területi tőkéjétől, annak néhány dimenziójától. A kapcsolati tőke és a gazdasági tőke mentén sikerült a legmegfelelőbben szétválasztani a kistérségeket, ami alapján a vándorlások legfőbb mozgatórugója a jobb megélhetés keresése, mely együtt jár néhány immateriális tényező (kulturális és humán tőke) iránti kereslettel. A számítások kimutatták, hogy az endogén kapacitásoknak alig érezhető hatása van, valamint a szélesebb értelemben vett térségi vonzerő és a belföldi migráció között gyenge kapcsolat mutatható ki (Tóth 2014: 3-18).

Összességében elmondható, hogy mind a nemzetközi, mind a hazai kutatások esetén a területi tőke koncepció vizsgálatának széles palettája látható akár a bevont indikátorokról, tőketípusokról, akár az elemzés módszeréről beszélünk. A materiális és immateriális tényezők esetén is föként statisztikai módszerekre támaszkodnak, hiszen így válnak összehasonlíthatóvá és egységesen mérhetővé egy-egy adott térség jellemzői. Az ismertetett kutatások főként 
országok, régiók, városok és kistérségek összehasonlítására, rangsorolására vonatkoztak, 1-1 esetben volt cél egy adott települést mélységében megvizsgálni. Az alábbi 2. táblázatban összegzem a fenti kutatásokat a vizsgált területi egység, az alkalmazott fogalmak és tőketípusok, valamint a kutatási módszerek alapján.

\section{2. táblázat: A vizsgált kutatások összefoglalása}

\begin{tabular}{|c|c|c|c|}
\hline Szerző & Területi egység & Fogalmi háló elemei & Kutatási módszer \\
\hline $\begin{array}{c}\text { Affuso és } \\
\text { Camagni (2010) }\end{array}$ & $\begin{array}{l}\text { olasz, francia és } \\
\text { spanyol régiók }\end{array}$ & $\begin{array}{l}\text { infrastrukturális tőke és települési } \\
\text { struktúra, ágazati és természeti } \\
\text { sajátosságok, kognitív tőke és } \\
\text { társadalmi tőke, növekedési } \\
\text { különbségek }\end{array}$ & $\begin{array}{l}\text { új ökonometriai } \\
\text { modell kidolgozása }\end{array}$ \\
\hline $\begin{array}{l}\text { Martinoa és } \\
\text { Pompili (2015) }\end{array}$ & $\begin{array}{c}\text { olasz } \\
\text { tartományok }\end{array}$ & $\begin{array}{c}\text { versenyképesség, vonzóerö, } \\
\text { természeti-kulturális tőke, humán } \\
\text { tôke }\end{array}$ & $\begin{array}{l}\text { klaszterelemzés és } \\
\text { faktoranalízis }\end{array}$ \\
\hline $\begin{array}{l}\text { Tortora et al. } \\
\qquad(2014)\end{array}$ & Vinci & $\begin{array}{l}\text { természeti tőke, kulturális örökség, } \\
\text { a turizmus fejlesztésének irányai }\end{array}$ & $\begin{array}{l}\text { fókuszcsoportos } \\
\text { interjú }\end{array}$ \\
\hline Dezio (2020) & $\begin{array}{l}\text { Olaszország } \\
\text { belső vidéki } \\
\text { területei }\end{array}$ & $\begin{array}{l}\text { kulturális tőke, természeti tőke, } \\
\text { humán tőke és gazdasági tőke, } \\
\text { mezőgazdaság kulturális öröksége }\end{array}$ & $\begin{array}{l}\text { dokumentum- } \\
\text { elemzés kritikai } \\
\text { megközelítéssel }\end{array}$ \\
\hline $\begin{array}{c}\text { Bogdanov és } \\
\text { Jankovic (2013) }\end{array}$ & Szerbia régiói & $\begin{array}{l}\text { vidéki területek fejlesztése a } \\
\text { turizmussal összefüggésben, a } \\
\text { területi tőke különböző dimenziói }\end{array}$ & $\begin{array}{l}\text { kvantitatív technikák } \\
\text { + interjútechnika }\end{array}$ \\
\hline $\begin{array}{c}\text { Fratesi és } \\
\text { Perucca (2014) }\end{array}$ & $\begin{array}{l}\text { közép-kelet- } \\
\text { európai régió } \\
\text { NUTS3-as } \\
\text { térségei }\end{array}$ & $\begin{array}{l}\text { strukturális jellemzők, gazdasági } \\
\text { növekedés és az Európai Unió } \\
\text { pénzügyi támogatásai között } \\
\text { fennálló kapcsolat, egy főre eső } \\
\text { regionális GDP alakulása }\end{array}$ & regresszió-elemzés \\
\hline $\begin{array}{c}\text { Fratesi és } \\
\text { Perucca (2020) }\end{array}$ & az EU régiói & $\begin{array}{l}\text { az EU regionális politikájának és a } \\
\text { területi tőkének az összefüggései, } \\
\text { fejlesztéspolitikai folyamatok } \\
\text { megértése és javítása, régiók } \\
\text { osztályozása a területi tőkéjük } \\
\text { szempontjából, GDP növekedés és } \\
\text { kohéziós politika hatékonyságának } \\
\text { összefüggései }\end{array}$ & regresszió-elemzés \\
\hline $\begin{array}{l}\text { Dodescu et al. } \\
\qquad(2018)\end{array}$ & $\begin{array}{l}\text { Románia } \\
\text { NUTS3-as régiói } \\
\text { (megyék) } \\
\text {. }\end{array}$ & $\begin{array}{c}\text { a területi tőke különböző } \\
\text { dimenzióinak hatása a gazdasági } \\
\text { növekedésre, gazdasági, } \\
\text { infrastrukturális, intézményi, } \\
\text { emberi és társadalmi tőke, a területi } \\
\text { tőkekomponensek és a gazdasági } \\
\text { növekedés kapcsolata }\end{array}$ & $\begin{array}{l}\text { strukturális } \\
\text { egyenletmodellezés } \\
\text { módszertana (SEM) }\end{array}$ \\
\hline
\end{tabular}




\begin{tabular}{|c|c|c|c|}
\hline $\begin{array}{c}\text { Tóth Balázs } \\
\text { István (2011) }\end{array}$ & $\begin{array}{c}\text { magyar } \\
\text { középvárosok }\end{array}$ & $\begin{array}{l}\text { területi tőke, materiális és } \\
\text { immateriális tényezők, rangsor } \\
\text { felállítása, csoportosítás }\end{array}$ & $\begin{array}{l}\text { faktorelemzés, } \\
\text { klaszteranalízis }\end{array}$ \\
\hline $\begin{array}{c}\text { Bodnár Gábor } \\
\text { (2016) }\end{array}$ & $\begin{array}{c}\text { magyar } \\
\text { kistérségek }\end{array}$ & $\begin{array}{c}\text { tőketényezők megjelenésének és } \\
\text { azok térszerkezetének } \\
\text { összehasonlítása, a területegységek } \\
\text { tőkeellátottsága, } \\
\text { endogén fejlődés, magán állótőke, } \\
\text { humán erőforrás, társadalmi tőke, } \\
\text { infrastrukturális tőke, kulturális } \\
\text { tőke és a vállalkozási környezet }\end{array}$ & faktoranalízis \\
\hline $\begin{array}{l}\text { Kovács-Bodnár } \\
\text { (2016) }\end{array}$ & $\begin{array}{l}\text { magyar vidékies } \\
\text { kistérségek }\end{array}$ & $\begin{array}{c}\text { a területi tőkével és endogén } \\
\text { fejlődéssel kapcsolatos } \\
\text { tőketényezők, a kulturális tőke, } \\
\text { humán erőforrás, infrastrukturális } \\
\text { tőke, társadalmi tőke és a } \\
\text { vállalkozási környezet befolyása a } \\
\text { magán állótőkére }\end{array}$ & $\begin{array}{l}\text { útelemzés } \\
\text { módszertana } \\
\text { (egymásra épülö } \\
\text { regressziós } \\
\text { modellek) }\end{array}$ \\
\hline $\begin{array}{l}\text { Tóth Balázs } \\
\text { István (2014) }\end{array}$ & $\begin{array}{l}\text { magyar } \\
\text { kistérségek }\end{array}$ & $\begin{array}{l}\text { területi tőke dimenziói, belföldi } \\
\text { állandó vándorlások száma }\end{array}$ & $\begin{array}{l}\text { diszkriminancia- } \\
\text { elemzés }\end{array}$ \\
\hline
\end{tabular}

Forrás: Saját szerkesztés a dolgozatban bemutatott kutatások alapján.

\section{Konklúzió - A területi tőke szerepe a vidékfejlesztésben}

A vidék alakulásának rövid áttekintése és a területi tőke bemutatása után megállapíthatóvá válik a területi tőke szerepe. Az alábbiakban kifejtem, hogy miért érdemes a területi tőke koncepcióját a vidéki térségek fejlesztése esetén alkalmazni.

A területiség elvének bevonása napjaink vidékfejlesztési trendjeiben éppúgy elengedhetetlen, mint a területi tőke szempontjából, mivel a NUTS3-as területi lehatárolás az alapja a magyarországi Vidékfejlesztési Programnak, a területi tőke pedig egy adott területi egység tőkeegyüttesét vizsgálja. Az természetesen nem kikötés, hogy minden esetben csak NUTS3-as térség fejleszthetö, ahogy az sincs köbe vésve, hogy mekkora területi egységet mérünk fel. A szubszidiaritás elve is alapvető napjaink vidékfejlesztési stratégiájában, hiszen a helyi döntések helyben megszületése és alkalmazása rendkívüli fontossággal bíró szempont. Az endogén kezdeményezést, vagyis alulról jövő elképzelések megvalósítását és a helyi beavatkozásokat a területi tőke koncepciója előtérbe helyezi (Jóna 2013: 32).

A fejlesztési elképzelések és a területi tőke stratégiai szempontból ugyanúgy a helyzetfelmérésen, az adatok és eredmények értékelése után pedig a cselekvésen alapul. Kiemelt mozzanat a helyi erőforrások és kapacitások meghatározása, mely a fejlesztési koncepció alapját képezi, hogy a helyi szükségletekhez igazodva alakíthassák a megoldásokat. A helyhez kötődő tőketípusok felhasználása a vidékfejlesztési elképzelések szempontjából is nagy jelentőséggel bír. 
Az átfogó, a mindennapi élet több területére is kiterjeszthető fejlesztések érdekében nagyon fontos a Corki Nyilatkozatban megfogalmazott integrált megközelítésmód, mely szempont világosan látszik a dolgozatban leírtaknál (Kovács 2012: 96-97). Ez az igény a területi tőke kutatásokban is kitünik, hiszen a „tőkét” nem csak gazdasági megközelítésben alkalmazzák.

A Vidékfejlesztési Program (2011) a fejlesztés első lépcsőjeként egy SWOT elemzés elkészítését és a szükségletek felmérését tüzte ki. A területi tőke keretrendszer ennek egy részletesebb, rétegzettebb és számszerüsíthető kiegészítése lehet, amely alaposabb elemzésre adhat lehetőséget. Épp úgy meghatározhatók az erősségek és a gyengeségek, valamint a lehetőségek és a veszélyek is. Azt, hogy mindezeket az elemzéseket mekkora területi egységre és milyen mutatók, indikátorok bevonásával végezzük el, az a kutatóra és a vizsgált jelenségre van bízva.

A területi tőke funkciója tehát kettős. Egyrészt nagy szerepe van adott térség tőke összetételének és mennyiségének felmérésében, mely mozzanat segít meghatározni a fejlesztendő területeket, hogy mely ágazat fejlesztése nélkülözhetetlen mások fellendítéséhez. Ez alapján választhatók ki a fejlesztés irányai, az alkalmazni kívánt pályázati források és a projektek célrendszerei, mely mozzanat hiánypótló lenne a projektforrások megfelelő elosztásában. Másrészt a beavatkozások közben, illetve után megállapítható, hogy mely fejlesztések tekinthetők hatékonynak vagy kevésbé hatékonynak adott térség szempontjából.

Végül az elemzésbe bevonandó utolsó szempont azokra a kulcsszereplőkre vonatkozik, akik nélkül semmilyen fejlesztés és felmérés nem valósulhatna meg. Az alkalmazkodó képesség, a kooperáció és a kapcsolati hálók alakítása mind olyan tényezők, melyek egy vidékfejlesztési tevékenységhez nélkülözhetetlenek. Az országos hálózati szereplők, a bürokrácia résztvevői, a projektosztály tagjai, a polgármesterek, az önkormányzati adminisztrációért felelők mind olyan aktorok, akik a projektesítésben közvetlenül vagy közvetve, de részt vesznek. A helyi gazdaságban érintett vállalkozók, a civil szervezetek, a közösségfejlesztők, az aktív lakosok és a hozzájuk kapcsolódó tevékenységek szintén kiemelendők. Mindezek mellett fontos szerepet tulajdonítok a kutatóknak és az elvégzett vizsgálatoknak, melyek egyrészt felmérik, másrészt bizonyítják, valamint megkérdőjelezik a fejlesztések helyességét és az alkalmazott módszerek hasznosíthatóságát.

\section{Irodalom}

Affuso, Antonio - Camagni, Roberto (2010): Territorial capital and province performance in the Latin Arch: an economettic approach. Milan: Italian Association of Regional Sciences.

Elérhető: http://www.grupposervizioambiente.it/aisre/pendrive2010/pendrive/paper/affuso1.pdf (Letöltve: 2019.12.18.)

Amodio, Teresa - Bencardino, Massimiliano - Iovino, Giorgia - Siniscalchi, Silvia (2019): Emerging topics in Italy: the territorial capital value. Bollettino della Società Geografica Italiana, 14(2): 75-89. 
Bodnár Gábor (2016): Az endogén fejlödés tényezőinek vizsgálata a vidék szemszögéböl. In Lengyel I. - Nagy B. (szerk.): Térségek versenyképessége, intelligens szakosodása és újraiparosodása, Szeged: JATEPress, 162-184. Elérhető: http://acta.bibl.u-szeged.hu/44070/1/gtk_2016_162-184.pdf (Letöltve: 2019.12.18.)

Bodnár Gábor - Kovács Péter (2016): Az endogén fejlődés értelmezése vidéki térségekben PLS-útelemzés segítségével. Statisztikai Szemle, 94(2): 144-161.

Bogdanov, Natalja - Jankovic, Dejan (2013): Territorial capital of rural areas: an example of analaysis of the potential for rural tourism development in Serbia. In Skoric, Dragan Tomic, Danilo - Popovic, Vesna (szerk.): Agri food sector in Serbia. Belgrad: Serbian Association of Agricultural Economics, 201-232. Elérhető: https://ideas.repec.org/b/ags/saaemn/157552.html (Letöltve: 2019.12.10.)

Bognár László - Csizmady Adrienne - Tamás Pál - Tibori Timea (2005): Problématérkép. Nemzetfelfogások - Falupolitikák. Budapest: ÚMK - MTA SZKI.

Bourdieu, Pierre (1998): Gazdasági tőke, kulturális tőke, társadalmi tőke. In Lengyel György Szántó Zoltán (szerk.): Tőkefajták: A társadalmi és kulturális erőforrások szociológiája. Budapest: Aula Kiadó, 155-176.

Bőhm Antal (2005): Gondolatok a magyar faluról, helyi társadalmáról és jövőjéről. In Bognár László - Csizmady Adrienne - Tamás Pál - Tibori Timea (szerk.): Problématérkép. Nemzetfelfogások - Falupolitikák. Budapest: ÚMK - MTA SZKI, 76-83.

Camagni, Roberto (2008): Regional competitiveness: towards a concept of territorial capital. In Capello, Roberta - Camagni, Roberto - Chizzolini, Barbara - Fratesi, Ugo (szerk.): Modelling Regional Scenarios for the Enlarged Europe. Berlin - Heidelberg: Springer, 33-47.

Dezio, Chaterine (2020): Restart from resources. rural heritage as antifragile territorial capital. Journal valori e valutazioni, 209(24): 209-217. Elérhető:

https://re.public.polimi.it/retrieve/handle/11311/1141044/524643/_DEZIO_VALORI \%20E\%20VALUTAZIONI_2020.pdf (Letöltve: 2020.09.18.)

Dodescu, Anca-Otilia - Botezat, Elena - Aurelia - Costangioara, Alexandru - Bolos, MarcelIoan (2018): An exploratory analysis of the territorial capital and economic growth: evidance from Romania. Economic Computation and Economic Cybernetics Studies and Research, 52(4): 95-112.

Dombi Gábor - Horváth Áron - Fodor-Kun Eszter - Kabai Gergely - Oláh Miklós - Sápi Zoltán - Szabó Pál - Tóth Balázs István (2017): A területi tőke és magyarországi dimenziói. Balatonfüzfö: A Nyilvánosságért és Civil Társadalomért Alapítvány.

Font Erzsébet (1999): A vidék gondja globális vagy lokális kérdés? In Pócs Gyula (szerk.): Vidékfejlesztés, vidékpolitika. Budapest: Agroinform Kiadóház, 7-18. 
Fratesi, Ugo - Perucca, Giovanni (2014): Territorial capital and the effectiveness of cohesion policies: an assessment for CEE regions. Investigaciones Regionales, 2014(29): 165191.

Fratesi, Ugo - Perucca, Giovanni (2020): EU regional policy effectiveness and the role of territorial capital. In Della Torre, Stefano - Cattanetto, Sara - Lenzi, Camilla - Zanelli, Alessandra (szerk.): Regeneration of the Built Environment from a Circular Economy Perspective. New York: Springer, 29-36.

Jóna György (2013): A területi tőke fogalmi megközelítései. Tér és Társadalom, 27(1): 30-51.

Juhász Pál (2005): Falusi társadalom. In Bognár László - Csizmady Adrienne - Tamás Pál Tibori Timea (szerk.): Nemzetfelfogások - Falupolitikák. Budapest: ÚMK - MTA SZKI, 42-50.

Kovács Teréz (1999): A vidékfejlesztés problémái és feladatai. In Pócs Gyula (szerk.): Vidékfejlesztés, vidékpolitika. Budapest: Agroinform Kiadóház, 167-178.

Kovács Teréz (2012): Vidékfejlesztési politika. Budapest-Pécs: Dialóg Campus Kiadó.

Kulcsár László (1999): Falvaink fejlesztési stratégiái az EU csatlakozás tükrében. In Pócs Gyula (szerk.): Vidékfejlesztés, vidékpolitika. Budapest: Agroinform Kiadóház, 179_ 194.

Kulcsár László (2017): A vidékfejlesztés elméleti megközelitése: regionális és kulturális összefüggések. Kolozsvár: Kriterion Könyvkiadó.

Ludescher Gabriella (2007): A vidékfejlesztés ,ppuha” módszerei. In Kovács Teréz (szerk.): A vidéki Magyarország az EU-csatlakozás után. VII. Falukonferencia. Pécs: MTA Regionális Kutatások Központja, 429-435.

Ludescher Gabriella (2010): A vállalkozások és a közösségek szerepe a rurális térségek megújulásában. Pécs: Publikon Kiadó.

Magyarország - Vidékfejlesztési Program 2014 - 2020. Elérhető: https://www.palyazat.gov.hu/node/56582\# (Letöltve: 2021. 06. 26.)

Martinoia, Michela - Pompili, Tomaso (2015): Building synthetic indicators for aspects of territorial capital. Liuc Papers, Serie Economia e Impresa, 290(78): 1-39. Internet: http://www.biblio.liuc.it/liucpap/pdf/290.pdf (Letöltve: 2020.09.18.)

Pásztohy András (2007): Paradigmaváltás a vidékfejlesztésben. Mit tesz a magyar kormány a vidékfejlesztés elősegítése érdekében? In Kovács Teréz (szerk.): A vidéki Magyarország az EU-csatlakozás után. VII. Falukonferencia. Pécs: MTA Regionális Kutatások Központja, 17-21.

Rechnitzer János (2010): Területi politika és vidékpolitika - együtt és külön. In Glatz Ferenc (szerk.): Sikeres vidéki térségek. Budapest: MTA Történettudományi Intézet-MTA Társadalomkutató Központ, 17-32. 
Reisinger Adrienn (2010): A civil társadalom, mint a sikeres vidék záloga. In Glatz Ferenc (szerk.): Sikeres vidéki térségek. Budapest: MTA Történettudományi Intézet - MTA Társadalomkutató Központ, 153-174.

Tortora, Marco - Randelli, Filippo - Romei, Patrizia (2014): A conceptual framework for tourism transition areas based on territorial capital: a case study of Vinci. Tourism, and Hospitality, $3(3)$ :

Elérhető: https://flore.unifi.it/retrieve/handle/2158/951338/142062/a-conceptualframework-for-tourism-2167-0269.1000135.pdf (Letöltve: 2019.12.10.)

Tóth Balázs István (2011): A magyar középvárosok teljesítménye a területi tőke tükrében. Területi Statisztika, 51(5): 530-543.

Tóth Balázs István (2014): A hazai kistérségek vonzerejének és területi tőkéjének néhány összefüggése. Területi Statisztika, 54(1): 3-18.

Varga Gyula (2005): Sokszínü falu - változóban. In Bognár László - Csizmady Adrienne Tamás Pál - Tibori Timea (szerk.): Nemzetfelfogások-Falupolitikák. Budapest: ÚMK - MTA SZKI, 59-75. 